\title{
The Influence of Curriculum Based on the Indonesian National Qualifications Framework (KKNI) on the Quality of Student Learning (Studies on Students at the State University of Medan)
}

\author{
Blasius Erik Sibarani \\ Faculty of Economics, Department of Accounting Education \\ Medan State University, Medan \\ e-mail: blasiussibarani@gmail.com
}

Sibarani, B. E. (2021). The Influence of Curriculum Based on the Indonesian National Qualifications Framework (KKNI) on the Quality of Student Learning (Studies on Students at the State University of Medan). Aptisi Transactions on Technopreneurship (ATT), 3(2), $56-65$.

DOI: https://doi.org/10.34306/att.v3i2.179

\begin{abstract}
The curriculum is one of the supporting factors of successful learning and of course the curriculum is structured to be able to improve the quality of each student. Currently the current curriculum is being discussed, namely the curriculum based on the Indonesian national qualification framework (KKNI). This curriculum is very closely related to the HOTS system (High Order Thinking Skill), where this system requires students to think at a high-level that requires a variety of different learning and teaching steps by just learning facts and concepts alone. The KKNI curriculum requires students to go directly into the real world / field. This curriculum is also expected to be able to harmonize cognitive, psychomotor, and affective. The purpose of this study was to find out and analyze the influence of KKNI on the quality of student learning. Data collection techniques are by distributing questionnaires to respondents as many as 40 respondents. The research method used in this study is by using a correlational method that is related to the descriptive method, where the writer will look for the relationship between the variables studied, namely the KKNI towards the quality of student learning. The research approach used by the writer is by using qualitative and quantitative approaches. The results showed that there was an influence of the KKNI curriculum on the quality of student learning. The research method used in this study is by using a correlational method that is related to the descriptive method, where the writer will look for the relationship between the variables studied, namely the KKNI towards the quality of student learning. The research approach used by the writer is by using qualitative and quantitative approaches. The results showed that there was an influence of the KKNI curriculum on the quality of student learning. The research method used in this study is by using a correlational method that is related to the descriptive method, where the writer will look for the relationship between the variables studied, namely the KKNI towards the quality of student learning. The research approach used by the writer is by using qualitative and quantitative approaches. The results showed that there was an influence of the KKNI curriculum on the quality of student learning.
\end{abstract}

Keywords: Curriculum, HOTS, KKNI

\section{Preliminary}

Education plays a very important role in the progress of the country. Education is a conscious and planned effort to create a learning atmosphere and learning process so that students can actively develop their potential to have religious spiritual strength, intelligence, 
skills needed for themselves, noble character, and self-control (UU RI No. 20 of 2003). Learning is part of the educational process". This opinion is in line with the view which reveals that "the success or failure of educational attainment depends on how the learning is experienced by students in school". "Learning is a system, consisting of several components which include: methods, objectives, materials.

Learning is at its peak when individuals can exercise choice over what and when they learn, and when they feel like they control their own learning". "Learning is at its peak when individuals can make choices about what and when they learn, and when they feel like they are in control of their own learning."

Currently, the era has entered a modern era and has entered the era of the industrial revolution 4.0. Every time there are changes that can affect human life, for that inevitably we as living beings must follow the development of an increasingly sophisticated era. Due to the advancement of the times, every human being, especially students, especially students are required to have good quality and have competitiveness so that in the future they do not experience being left behind by others. At this time the quality of Indonesian students is still relatively low, so that with the low quality of students, the level of quality of human resources is also low. To improve the quality of students, those who play a role in it are university/college education. How the system in college will affect the quality of a student. The better the system in a university, the more likely the quality of its students is high, and vice versa.

Currently, almost all universities in Indonesia have started to implement a curriculum based on the Indonesian National Qualifications Framework (KKNI). Every decision making will certainly reap the pros and cons, as well as the implementation of the KKNI-based curriculum which makes some students feel burdened by the implementation of the curriculum and not a few students feel that the implementation of this curriculum will make students feel challenged with all their duties and responsibilities. answer given to each student. The government as the holder of control over the curriculum that will be used by each university certainly has a goal to be achieved. The main purpose of implementing this curriculum as stated in the guide to the preparation of the higher education curriculum is that there are four learning outcomes in the KKNI, namely elements of attitudes and values, elements of work ability, elements of scientific mastery, elements of authority and responsibility. The four elements that have been determined will be needed in the world of work. As a millennial generation who will become leaders and actors in various sectors in Indonesia, of course these four elements will be indispensable in order to become people who can be useful for Indonesia.

The use of the KKNI-based curriculum has become the right step in the process of improving the quality of students. Because in addition to teaching knowledge, it will also teach how the individual can behave and be responsible. Because as the spearhead not only must have knowledge but also a responsible attitude. This is what makes the government issue a new education system that aims to make students more qualified and responsible. As for the formulation of the problem in this study, how is the influence of KKNI on the quality of students? The purpose of this study is to find out the influence of the KKNI-based curriculum on the quality of student learning.

\subsection{Research Methods}

\subsection{Types of research}

This type of research is a correlational study that involves collecting data to determine whether there is a relationship between the implementation of the KKNI on the quality of students. This study uses a qualitative approach combined with a quantitative approach by looking at phenomena and to measure the effect of the KKNI-based curriculum on the quality of student learning.

\subsection{Population and Sample}

In this study, the population used by the author was all students of the Faculty of Economics, State University of Medan Stambuk and 2017. The samples in this study were 40 students of the Accounting Education Study Program.

\subsection{Sources and Data Collection Techniques}


In this study, the primary data is data obtained from respondents through questionnaires. Data collection techniques in this study using a questionnaire. The questionnaire was delivered by distributing it directly to 40 students who were the research sample. In this study, scoring was made using a modified Likert scale.

\subsection{Research Methods Used}

This research is planned to be conducted using two methods, namely descriptive and verification or causality. Through this research, it is expected to be able to describe the characteristics of the KKNI and the quality of student learning. This research is expected to be able to examine the effect of the KKNI on the quality of student learning.

\section{Literature Review}

\subsection{Curriculum}

The curriculum is an important component that is very decisive in the education system unit, and is a tool to achieve educational goals and at the same time as a guide in the implementation of teaching at all types and levels of education. The curriculum serves as a guide in the implementation of educational activities in schools for related parties, either directly or indirectly. From the expert's statement above, it can be concluded that the curriculum is basically an important component that functions as a guide in the continuity of the education system and as a means of achieving the goals of education.

This curriculum program is structured to provide learning opportunities for children to build their experiences in the process of transmitting, negotiating and transforming skills, values and character under the guidance of educators in decision making and simple problem solving in the physical and cultural environment in the learning process to match the experiences that children already have with new experiences to form new concepts about the environment and existing societal norms.

There are three curriculum concepts, namely the curriculum as a substance, a document containing the formulation of objectives, teaching materials, teaching and learning activities, schedule and evaluation. The curriculum as a system includes personnel structures, and work procedures on how to develop a curriculum, implement, evaluate, and perfect it. Curriculum as a field of study, namely the field of curriculum study. The purpose of the curriculum as a field of study is to develop knowledge about the curriculum and curriculum system.

Regulation provides direction on the need to develop and implement the eight national education standards: 1) standard of content, 2) standard of process, 3) standard of competency graduates, 4) standard of teachers and staffs, 5) standard of facilities and infrastructure , 6) standard of management, financing, and 6) standard of assessment in education.

The implementation of curriculum development must go through the following stages: 1) feasibility study and needs analysis, 2) curriculum planning, 3) curriculum operational plan development, 4) implementation of a limited trial curriculum in the field, 5) implementation curriculum, 6) curriculum monitoring and evaluation, 7) improvement and adjustment.

\subsection{Indonesian National Qualifications Framework}

The Indonesian National Qualifications Framework (KKNI) is a reference for competency qualification levels for job recognition. The KKNI was formulated by the Minister of Education and Culture in 2010 as a reference for curriculum development. The KKNI was then promulgated through Presidential Regulation Number 8 of 2012 concerning the Indonesian National Qualifications Framework. The presence of the KKNI is actually a general reference for how a person's qualifications are recognized in the world of work. The Minister of Education and Culture explained that Indonesia's need to immediately have an $\mathrm{KKNI}$ is very urgent considering the challenges and global competition of the national and international labor markets are increasingly open.

$\mathrm{KKNI}$ is a leveling of competency qualifications that can juxtapose, equalize, and integrate between the education and job training fields in accordance with the work structure in 
various sectors (Perpres No. 8 of 2012 Article 1 Paragraph (1)). With this KKNI, quality, productive and professional human resources will be formed. There are three KKNI development strategies. First, KKNI adheres to a strategy of equal qualification of one's qualifications obtained from the world of formal, non-formal, informal education and work experience. Second, KKNI recognizes the qualifications of diploma holders who will work or continue their education abroad, exchange experts and cross-border students or diploma holders from abroad who work in Indonesia. Third, KKNI recognizes the equality of qualifications for learning outcomes in various scientific fields at the level of higher education, both in the academic, vocational, professional education pathways, as well as through career development that occurs in work strata, industry or professional associations. KKNI consists of 9 levels of qualification. Description of KKNI qualification levels according to Presidential Decree No. 8 of 2012 is described in chart 1.

1. Levels 1 to 3 are grouped into operator positions occupied by elementary, middle and high school graduates.

2. Levels 4 to 6 are grouped into technician or analyst positions, occupied by graduates of D1, D2, D3, D4 and Bachelor's degrees.

3. Level 7 is grouped into expert positions, occupied by graduates of professional education.

4. Level 8 is grouped into expert positions occupied by master or specialist 1 graduates.

5. Level 9 is grouped into expert positions occupied by doctoral graduates or doctoral specialists

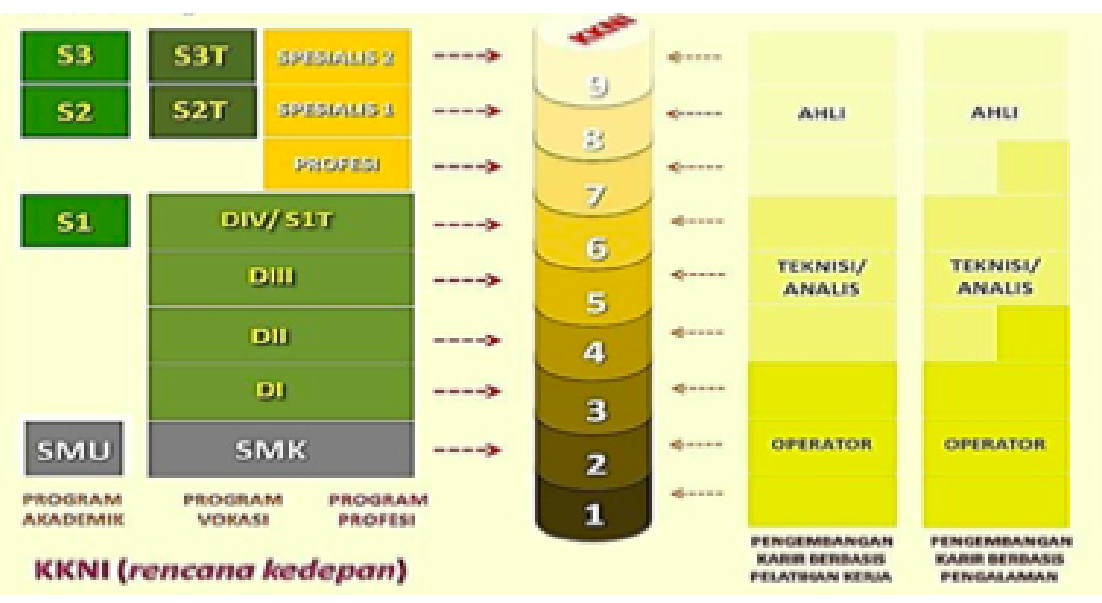

Chart 1. KKNI Description According to Prepres No. 8 Year 2012 (Dikti.org)

Conceptually, each qualification level in the $\mathrm{KKNI}$ is composed of four parameters, namely: (1) work skills, (2) scientific scope (knowledge), (3) methods and levels of ability to apply knowledge, and (4) managerial abilities (Mendikbud, 2010:18).In the long term, the implementation of the KKNI will have an impact on:

a. Increasing the quantity of quality and internationally competitive Indonesian human resources in order to ensure an increase in the accessibility of Indonesian human resources to the national and international job markets;

b. Increasing the contribution of learning outcomes obtained through formal, non-formal, informal education, or work experience in national economic growth;

c. Increased academic mobility to increase mutual understanding, solidarity and cooperation in higher education between countries in the world;

d. Increased recognition of other countries, both bilaterally, regionally, and internationally to Indonesia without leaving the characteristics and personality of the Indonesian nation. 


\section{Research Hypothesis}

Based on the explanation above, the hypotheses in this study are:

Hypothesis 1: Parental attention affects students' study habits. Test the statistical hypothesis as follows:

$\mathrm{H} 0: 11=0 \mathrm{KKNI}$ has no effect on the quality of student learning

$\mathrm{H} 1: 110 \mathrm{KKNI}$ affects the quality of student learning real level or (0.05).

The test criteria is that $\mathrm{HO}$ is rejected if the value of sig is smaller than the value of the

\section{Results And Analysis}

\subsection{KKNI Curriculum Effectiveness}

A quality society can be seen from the education system used in the country. How the education system works depends on the laws that apply in a country, a developed country will certainly create a more advanced education system. If the education system is advanced, it is certain that the country has human resources who are ready to join the world of work. This is what the Indonesian Ministry of Education has done trying hard to be able to advance the quality of its human resources, with the Presidential Regulation No. 8 of 2012 and Law No. 12 of 2012 concerning Higher Education [10], all universities are required to be able to adapt to the current system. run. As one of the producers of human resources that can be expected, of course, every university can see the quality of its graduates, whether each graduate produced is really ready to face the world of work, and whether the graduates produced have abilities that are equivalent to the abilities expected by the world of work. In this case, of course, what every graduate needs to have is a balance between knowledge and attitude.

Implementation of the use of the KKNI curriculum in the field can be said to be going well, although it is still reaping the pros and cons both from within the campus, especially students. Through the implementation of this curriculum, it can be said that the government is getting serious and more intensive in terms of education. In the current education system, there are many tasks and responsibilities assigned to each student. Each student will get an assignment as in this curriculum there are six mandatory tasks given to students, while the tasks given are routine assignments, critical book reports, critical journal reviews, mini research, idea engineering, projects.

\subsection{Analysis of the Influence of KKNI on Student Quality \\ * Reliability Test}

\section{Reliability Statistics}

\begin{tabular}{|r|r|}
\hline $\begin{array}{c}\text { Cronbach's } \\
\text { Alpha }\end{array}$ & N of Items \\
\hline, 805 & 10 \\
\hline
\end{tabular}


Item-Total Statistics

\begin{tabular}{|l|r|r|r|r|}
\hline & $\begin{array}{c}\text { Scale Mean if } \\
\text { Item Deleted }\end{array}$ & $\begin{array}{c}\text { Scale Variance if } \\
\text { Item Deleted }\end{array}$ & $\begin{array}{r}\text { Corrected } \\
\text { Item-Total } \\
\text { Correlation }\end{array}$ & $\begin{array}{c}\text { Cronbach's } \\
\text { Alpha if Item } \\
\text { Deleted }\end{array}$ \\
\hline Item_1 & 26.98 & 10,640 &, 701 &, 761 \\
Item_2 & 27.08 & 10,225 &, 780 &, 750 \\
Item_3 & 26.88 & 10,625 &, 705 &, 761 \\
Item_4 & 27,00 & 11.333 &, 755 &, 765 \\
Item_5 & 26.88 & 12,010 &, 387 &, 798 \\
Item_6 & 26,80 & 12,164 &, 492 &, 789 \\
Item_7 & 26.88 & 10,522 &, 680 &, 763 \\
Item_8 & 26.93 & 13,046 &, 182 &, 815 \\
Item_9 & 26.88 & 12,163 &, 441 &, 792 \\
Item_10 & 27.05 & 12,869 &, 041 &, 861 \\
\hline
\end{tabular}

Source: SPSS 22 . output

Researchers conducted a reliability test to find out how reliable the statements contained in the questionnaire were so that through this test later we could conclude that the results would be categorized as good/measured or not. Based on the results of the reliability test above, it can be seen that the statements contained in the questionnaire distributed by the researchers were tested reliably and can be accepted. According to Guilford, there is an interpretation of the value of the reliability coefficient, namely:

\begin{tabular}{|c|c|}
\hline Reliability Coefficient & Interpretation \\
\hline $0.00 \leq \mathrm{r} 0.20<$ & Very low \\
\hline $0.20 \leq \mathrm{r} 0.40<$ & Low \\
\hline $0.40 \leq \mathrm{r} 0.60<$ & Moderate/Enough \\
\hline $0.60 \leq \mathrm{r} 0.80<$ & High \\
\hline $0.80 \leq \mathrm{r} 1.00<$ & Very high \\
\hline
\end{tabular}


So from these criteria, the researcher can conclude that the interpretation of the reliability coefficient of the test results above is classified as a very high/very reliable interpretation according to the criteria of the Guilford expert.

* Linearity Test

ANOVA Table

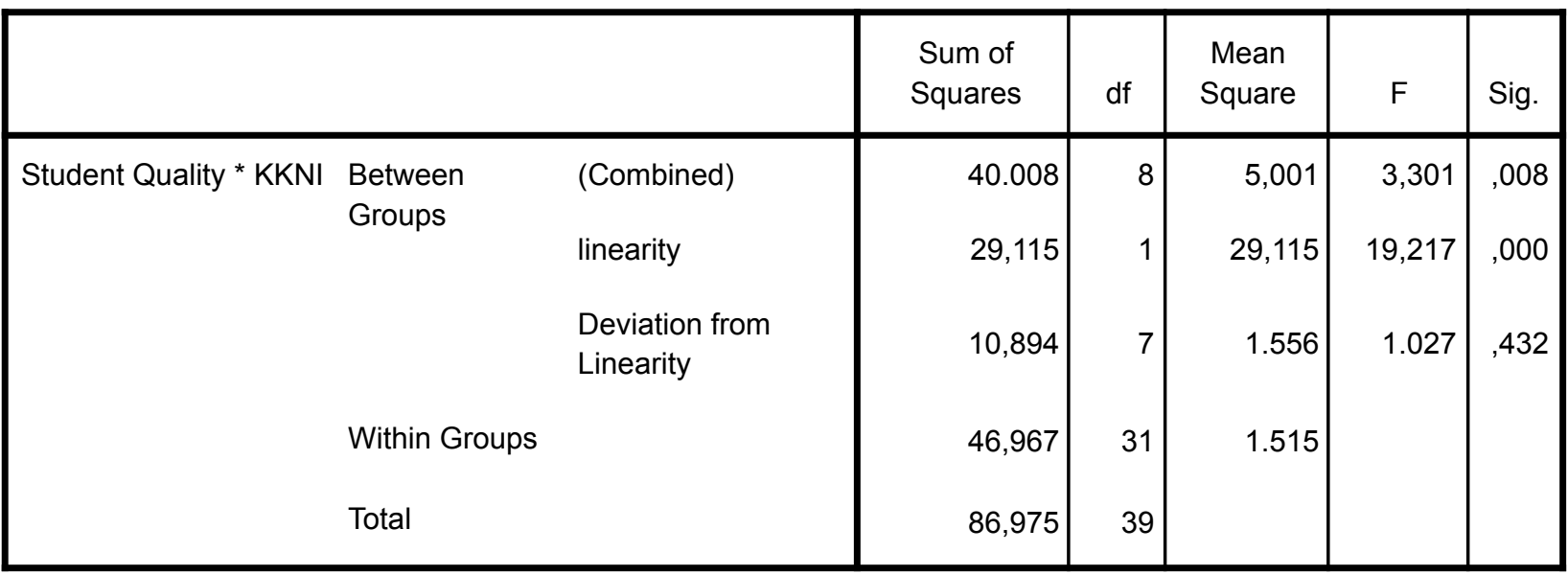

Source: SPSS 22. output

Based on the results of the linearity test ANOVA table above, the researcher can conclude that:

1. Based on the significance value (Sig): From the output above, the Deviation from Linearity Sig value is obtained. is 0.432 greater than 0.05 . So it can be concluded that there is a significant linear relationship between the $\mathrm{KKNI}$ variable $(\mathrm{X})$ and the student learning quality variable $(\mathrm{Y})$.

2. Based on the $F$ value From the output above, the calculated $F$ value is $1.027<F$ table 4.16. Because the calculated $F$ value is smaller than the table $F$ value, it can be concluded that there is a significant linear relationship between the KKNI variable $(X)$ and the student learning quality variable $(\mathrm{Y})$.

* Pearson Correlation Test

Correlations

\begin{tabular}{|ll|r|r|}
\hline & & KKNI & Student Quality \\
\hline KKNI & Pearson Correlation & 1 &, $579^{* *}$ \\
& Sig. (2-tailed) & &, 000 \\
& $\mathrm{~N}$ & 40 & 40 \\
Student Quality & Pearson Correlation &, $579^{* *}$ & 1 \\
& Sig. (2-tailed) &, 000 & \\
& N & 40 & 40 \\
\hline
\end{tabular}

${ }^{* *}$. Correlation is significant at the 0.01 level (2-tailed).

Source: SPSS 22 . output 
The correlation test table is used to determine the level of significance or linearity of a variable $X$ to variable $Y$. The criteria can be determined based on the significance value test (Sig), provided that the Sig value $<0.05$, if the Sig value $<0.05$ then there is a significant relationship between the variables. $X$ to variable $Y$, whereas if the value of Sig $>0.05$ then there is no significant relationship between variable $X$ and variable $Y$. Based on the table above, the Sig value is obtained. $=0.000$, means Sig. $<$ of the significant criteria $(0.05)$. Thus it can be concluded that there is a significant relationship between the Indonesian National Qualifications Framework (KKNI) on the quality of student learning.

\section{* Simple Linear Regression Test}

\begin{tabular}{|c|c|c|c|c|c|c|}
\hline \multicolumn{7}{|c|}{ ANOVAa } \\
\hline \multicolumn{2}{|c|}{ Model } & $\begin{array}{l}\text { Sum of } \\
\text { Squares }\end{array}$ & $\mathrm{df}$ & Mean Square & $\mathrm{F}$ & Sig. \\
\hline 1 & Regression & 29,115 & 1 & 29,115 & 19,121 &, $000 b$ \\
\hline & Residual & 57,860 & 38 & 1.523 & & \\
\hline & Total & 86,975 & 39 & & & \\
\hline
\end{tabular}

a. Dependent Variable: Student Quality

b. Predictors: (Constant), KKNI

Simple linear regression test table is used with the aim of knowing the influence between the independent variables on the dependent variable, whether it has an effect or not. Based on the results of the regression test output above, it is known that the calculated $F$ value $=19,121$ with a significance level of $0.000<0.05$, it can be concluded that the regression model can be used to predict the student learning quality variable or in other words there is an influence of the KKNI variable $(\mathrm{X})$ on the variable of Student Learning Quality $(\mathrm{Y})$.

\section{Coefficients}

\begin{tabular}{|c|c|c|c|c|c|c|}
\hline \multirow{2}{*}{\multicolumn{2}{|c|}{ Model }} & \multicolumn{2}{|c|}{ Unstandardized Coefficients } & \multirow{2}{*}{$\begin{array}{c}\begin{array}{c}\text { Standardized } \\
\text { Coefficients }\end{array} \\
\text { Beta }\end{array}$} & \multirow[b]{2}{*}{$\mathrm{t}$} & \multirow[b]{2}{*}{ Sig. } \\
\hline & & B & Std. Error & & & \\
\hline \multirow[t]{2}{*}{1} & (Constant) & 6,165 & 1.343 & & 4,591 & ,000 \\
\hline & KKNI &, 324 & ,074 & ,579 & 4,373 & ,000 \\
\hline
\end{tabular}

Based on the results of the regression test output for the Coefficients section, it is known that the constant (a) value is 6.165 , while the KKNI value (b/ regression coefficient) is 0.324 , so that the regression equation can be written:

$$
Y=a+b X
$$


The above equation means:

$$
Y=6.165+0.324 X
$$

$\checkmark$ The constant is 6.165 , meaning that the consistent value of the student learning quality variable is 6.165

$\checkmark$ The $\mathrm{X}$ regression coefficient of 0.324 states that for every $1 \%$ addition to the $\mathrm{KKNI}$ score, the value of Student Learning Quality increases by $0.324 \%$. The regression coefficient is positive, so it can be said that the direction of the influence of the KKNI variable $(\mathrm{X})$ on Student Learning Quality $(\mathrm{Y})$ is positive.

\section{Conclusion}

From the results of the tests that researchers have done with several tests, it can be concluded that 1) there is a significant linear relationship between the implementation of the KKNI-based curriculum on the quality of student learning as indicated by the results of the Linearity test output where the significance value is 0.432 while the $F$ value is 1.027 smaller. from $F$ table, 2) there is a significant relationship between the $\mathrm{KKNI}$ variable $(\mathrm{X})$ and the Student Learning Quality variable $(Y)$ which is indicated by the output of the Pearson correlation test, where the Sig value is obtained. $=0.000$, means Sig. $<$ from the significant criteria $(0.05), 3)$ there is a significant influence of the $\mathrm{KKNI}$ variable on the student learning quality variable as indicated by the output results of a simple linear regression test. With a coefficient value of 0.324 which is positive, 4) from the overall test results, it can be concluded by testing that there is a correlation between the KKNI-based curriculum on the quality of student learning. Based on the research that has been done and the results obtained, the research suggestion that can be applied is that the campus continues to run the KKNI-based curriculum system to be able to improve the quality of student learning. Because at this time there are still many students who are not serious in learning and just do their assignments or in other words "as long as they are ready". So the KKNI curriculum is very appropriate to run. In addition, the authors hope for future researchers to add variables or expand the scope of research to improve the quality of relevant research.

\section{References}

[1] A. Maksum, "Kurikulum dan pembelajaran di perguruan tinggi: menuju pendidikan yang memberdayakan," in Prosiding Seminar Nasional Hasil Penelitian Pendidikan dan Pembelajaran.(STKIP PGRI Jombang Jawa Timur, 2015), 2015, pp. 3-14.

[2] Departemen Pendidikan Nasional. 2003. Undang-Undang Nomor 20 Tahun 2003 tentang Sistim Pendidikan Nasional.

[3] B. S. N. Pendidikan, "Panduan Pengembangan Silabus Kurikulum Tingkat Satuan Pendidikan (KTSP)," Jakarta CV. Laksana Mandiri, 2006.

[4] C. Casmini, "Evaluasi Dan Peninjauan Kurikulum Bki Berbasis Kkni," Hisbah J. Bimbing. Konseling dan Dakwah Islam, vol. 11, no. 1, pp. 125-144, 2014.

[5] Kemendikbud (2014c). Peraturan Menteri Pendidikan dan Kebudayaan Republik Indonesia nomor 50 tahun 2014 tentang sistem penjaminan mutu pendidikan tinggi. Jakarta: Kemendikbud. diganti kebijakan pengemebngan kurikulum sekolah"

[6] D. P. Nasional, "Pelaksanaan Standar isi dan Standar kompetensi Kelulusan." Jakarta, 2006.

[7] I. Q. Framework, "Buku Pedoman Kerangka Kualifikasi Nasional," Edisi. 1. Direktorat Jenderal Pendidik. Tinggi. Kementeri. Pendidik. Nas. RI, 2010.

[8] S. Johnson, S. Veitch, and S. Dewiyanti, "A framework to embed communication skills across the curriculum: A design-based research approach," J. Univ. Teach. Learn. Pract., vol. 12, no. 4, p. 6, 2015.

[9] P. Presiden, "Peraturan Presiden Nomor 8 Tahun 2012 tentang Kerangka Kualifikasi 
Nasional Indonesia," Jakarta Pemerintah Republik Indones., 2012.

[10] Kemendikbud (2012b). Peraturan Presiden nomor 8 tahun 2012 tentang kerangka kualifikasi nasional Indonesia. Jakarta: Kemendikbud. 